\title{
Can Capital-Skill Complementarity Explain the Rising Skill Pre- mium in Developing Countries? Evidence from Peru in the 1990s
}

\author{
Joy Mazumdar ${ }^{\dagger}$, Myriam Quispe-Agnoli ${ }^{\mathrm{a}, \boldsymbol{}}$ \\ †In Memoriam

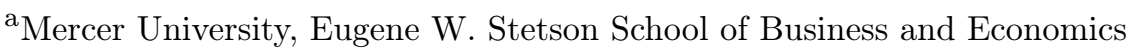 \\ $\bowtie$ quispe_mj@mercer.edu_ Corresponding author
}

\begin{abstract}
The unsettled discussion continues about the factors behind the increase in the relative wages of skilled workers in developing countries. Using data from Peru for the years 1994 to 2000, we analyze the determinants of within-industry share of skilled workers. We use a translog cost function for gross output and are therefore able to incorporate the effects of materials, both domestic and imported, in addition to capital. We find that capital accumulation can explain a large fraction of the increase in the wage bill share and relative wages of skilled labor. This finding is contrary to the commonly held view that unobservable technological change is responsible for the rising skill premium in both developing and developed economies. A test for separability indicates that a gross output cost function is the appropriate one to use, and therefore share equations based on value-added cost functions could be misspecified.
\end{abstract}

Article History: Received: 27 January 2019 / Revised: 17 May 2019 / Accepted: 21 June 2019 Keywords: Skill premium; Capital-skill complementarity; Capital accumulation; Peru. JEL Classification: F16, J31, O12, O54, E22

\section{Acknowledgements}

The authors gratefully acknowledge the regional team of the Research Department at the Federal Reserve Bank of Atlanta. They also thank Stanley Black, Pat Conway, Alfred Field, and participants of the International/Development Seminar of the University of North Carolina at Chapel Hill, and anonymous referees for helpful comments. They appreciate the editorial comments of Lynne Anservitz and Tom Heintjes. They thank Sarah Dougherty for research assistance. 


\section{Introduction}

Many developing countries have experienced an increase in the relative wages of skilled workers following trade liberalization, as has been well documented by now (see, for example, Robbins, 1996; Wood, 1997; Hanson and Harrison, 1999). Since this is contrary to the predictions of standard Heckscher-Ohlin model of trade, skilled biased technological change has been cited as a possible explanation for this phenomenon ${ }^{1}$. The rise in the skill premium (or the ratio of skilled labor wages to unskilled labor wages) observed in developing countries has been interpreted as an additional piece of evidence to support the claim that it is technology rather than trade that is driving the rise in relative wages in the industrialized world (Berman and Machin, 2000). A common way to demonstrate that skilled biased technological change has taken place is to show that the share of skilled workers in the wage bill within industries has increased over time (Berman et al., 1994; Berman and Machin, 2000). If the overall wage share of skilled workers in the economy is increasing due to trade, then one would expect to see that reallocations of labor between industries (from those with a low wage share of skilled workers to those with higher wage shares) driving this shift. On the other hand, if technology were the culprit, then these shares would be changing in the favor of skilled workers within industries.

The papers cited above find that most changes can be explained by within-industry changes ${ }^{2}$. Changes in the wage share of skilled labor within industries can be a good measure of shifts in relative demand. An increase in the wage share of skilled labor in the face of a rising skilled wage premium will indicate a shift in favor of this type of labor if we assume that the elasticity of substitution is greater than one. The literature cited in the previous paragraph has attributed these wage share changes to technology. However, within-industry changes in the share can be driven by factors other than technology. Since technological change is not directly observable, the studies mentioned above interpret the residual component of share changes that cannot be explained by measurable factors as the effects of technology ${ }^{3}$. The factors other than technology that could also influence the shares of skilled and unskilled labor include capital and materials. Skilled labor could be more complementary with physical capital than unskilled labor. Griliches (1969) formalized the hypothesis for such capital-skill complementarity and provided evidence for it. Krusell et al. (2000), in fact, argue that capital-skill complementarity can explain most of the change in the share of skilled labor in the United States (a view that is contrary to the rest of the literature). It is also possible for materials to affect the share of skilled labor. For example, material imports could substitute for unskilled labor in industrialized nations, as Feenstra and Hanson (1999) point out. While the effect of imported materials could go the other way in developing countries, it may be necessary to consider them to avoid misspecification.

\footnotetext{
${ }^{1}$ Other explanations include Davis (1996) and Feenstra and Hanson (1996). Davis argues that middle-income countries may be competing with low-income countries in a world with multiple cones of specialization, and so trade could reduce relative wages in these middle-income developing countries. According to Feenstra and Hanson, capital flows from the North to the South could increase the relative demand for skilled labor in both regions.

${ }^{2}$ Within-industry changes in developing countries are stronger in the 1980s compared to the 1970s (Berman and Machin, 2000).

${ }^{3}$ Berman et al. (1994) do relate changes in share to indicators of technology such as investment in computers and R\&D.
}

\section{(옹 PUCP}


So far, the effects of these other factors on changes in shares have been found to be small. Berman et al. (1994) find that while capital can explain some of the change in favor of skilled workers; it is able to account for only a small fraction of the shift. Berman and Machin (2000) also find that changes in capital intensity do not explain much. The effect of materials is usually not incorporated in these studies since they are based on cost functions for value added. Berman et al. (1994) try to take into account the effect of materials but find it to be unimportant.

The objective of this paper is to explore in detail the factors behind the increase in relative demand for skilled labor in a developing country, Peru in the 1990s. Our measure of relative demand will be the within-industry share of skilled labor. Specifically, we want to see how much factors such as capital and materials, compared to unobservable technology, can explain the increase in relative demand. It is interesting to conduct this exercise for developing countries for two reasons. First, capital accumulation is likely to be higher in developing countries compared to industrialized nations. If there are capital-skill complementarities then it is possible that capital accumulation can explain a larger fraction of the increase in demand for skilled labor in these countries compared to developed countries. The sample in the Berman and Machin paper does include developing countries. However, our paper conducts a more detailed analysis of the capital-skill complementarity issue in the following ways. We estimate the coefficient for capital intensity for Peru instead of using a calibrated coefficient from the literature, as they do. In addition, our data include information at a more disaggregated industry level, and we take into account the effects of materials. The second reason for looking at developing country data is that trade liberalization might stimulate investment in these countries since a significant fraction of equipment in developing countries has to be imported. If our results find capitalskill complementarities to be important, then trade may increase the relative demand for skilled workers via this mechanism.

A paper closely related to ours is that of Pavcnik (2003). She uses Chilean plant-level data from the late 1970s to the 1980s to analyze the determinants of the rising share of skilled workers and finds that investment played some role (she does not find any evidence that foreign technology had an effect). Our results are consistent with her findings, although we look at the 1990s for $\mathrm{Peru}^{4}$. We find strong evidence for capital-skill complementarity. We estimate the contribution of capital accumulation to the increase in the overall wage share and relative wages of skilled workers and find it to be important. One way our analysis differs from hers is that we take into account the role of materials using a gross output cost function while Pavcnik uses a value added cost function, as does most of the literature. Pavcnik does look at the effect of imported materials, introducing it as an indicator of foreign technology. As we discuss in the paper, gross output based cost functions may be more appropriate. In that case, the effect of imported materials has a different interpretation from the one in her paper.

Our main results are as follows. We find that increases in capital intensity are strongly and positively related to increases in the wage share of skilled workers. Capital accumulation can explain a large portion of the increase in share and relative wages of skilled labor. A test for separability indicates that a gross output cost function is the appropriate one to use. Share

\footnotetext{
${ }^{4}$ We use industry-level data since plant level data were not available for Peru.
} 
equations based on value added cost functions could suffer from misspecification.

The remainder of the paper is organized as follows: Section 2 gives a brief history of reforms in Peru in the early 1990s. It also presents the trends in wages and employment in Peru and shows that there has indeed been a shift in labor demand in favor of skilled labor during the decade of the 1990s. Section 3 presents the basic theoretical framework that provides the main determinants of the shares of skilled and unskilled workers in factor payments. Changes in these shares are interpreted as measures of relative demand shifts. The equation and its estimation method are discussed in this section. Section 4 describes the data and the results, and shows that capital accumulation can explain a large fraction of the shift in demand in favor of skilled workers. The last section contains our conclusions.

\section{Reforms Overview and Trends in Wages and Employment}

\section{Reforms in Peru}

Like many other developing countries during the last three decades, Peru implemented wide ranging structural reforms in early 1990s. President Alberto Fujimori's government eliminated price controls, subsidies, and foreign exchange restrictions. A flexible exchange rate was adopted in August 1990. There was a significant liberalization of the foreign trade regime and the average level of tariffs was reduced sharply, from 66 percent in 1989 to 15 percent in 1995 and to 12 percent in 1997. Import prohibitions, which were extensively used in the 1970s and the late 1980s, were gradually abandoned. Export restrictions were eliminated for most exports in 1991. There was also a substantial privatization drive and tax reform. After a recession in 1992, the country experienced GDP annual growth rates of more than 7 percent in the following five years. Inflation was much lower (with an average annual rate of around 20 percent) during this period.

Along with these reforms, Peru was one of the few countries in Latin America to implement significant reforms in the labor markets ${ }^{5}$. These reforms were focused on lowering worker dismissal costs, facilitating temporary hiring, and introducing flexibility in formal employment. Prior to labor reform, labor legislation was extremely complex and included a wide range of regulations, such as binding minimum wage policies, extremely high dismissal costs, administrative controls, and specific compulsory benefits, which introduced a series of distortions in labor markets. Peruvian labor legislation was modified through successive steps. The Law of Employment Promotion (Ley de Fomento al Empleo) of 1991 along with a new constitution in 1993 introduced several measures to reduce labor market rigidities. Later in 1995, new regulations followed to deepen the flexibility in labor markets. Consequently, workers' dismissal costs declined sharply through the progressive elimination of job security regulations, the introduction of temporary contracts, and changes in the severance payment structure.

Most of the effects of labor reform took place in 1991, and by 1995 labor markets seemed to have adjusted to new regulations. For example, the share of workers in private formal wage

\footnotetext{
${ }^{5}$ According to the Inter-American Development Bank, 2004 report, only six countries implemented significant labor reforms between the mid-1980s and 1999: Argentina (1991), Colombia (1991), Guatemala (1990), Panama (1995), Peru (1991), and Venezuela (1998).
} 
Table 1

Skill premium, share in wage bill, and annual wages.

\begin{tabular}{|c|c|c|c|c|c|c|c|}
\hline & 1994 & 1995 & 1996 & 1997 & 1998 & 1999 & 2000 \\
\hline $\begin{array}{l}\text { Skill premium }=\text { skilled to } \\
\text { unskilled wage ratio }\end{array}$ & 2.04 & 2.252 & 2.189 & 2.302 & 2.381 & 2.382 & 2.528 \\
\hline $\begin{array}{l}\text { Skilled to unskilled } \\
\text { employment ratio }\end{array}$ & 0.656 & 0.663 & 0.663 & 0.642 & 0.638 & 0.633 & 0.64 \\
\hline Skilled share in wage bill & 0.572 & 0.599 & 0.592 & 0.596 & 0.603 & 0.601 & 0.618 \\
\hline $\begin{array}{l}\text { Skilled real annual wages } \\
\text { (1994 nuevos soles) }\end{array}$ & 14,605 & 16,347 & 15,906 & 16,701 & 16,990 & 17,095 & 17,662 \\
\hline $\begin{array}{l}\text { Unskilled real annual } \\
\text { wages (1994 nuevos soles) }\end{array}$ & 7,159 & 7,258 & 7,267 & 7,254 & 7,136 & 7,178 & 6,985 \\
\hline
\end{tabular}

employment under temporary contracts increased from 20 percent in 1991 to 31 percent in 1992 and then to 40 percent in 1995. The increase from 1995 to 1997 was small (4 percentage points) compared to earlier years (Saavedra and Torero, 2000).

\section{Trends in Wages and Employment}

In our paper, we focus on the period 1994-2000 after the major labor market reforms had already taken place so that we may abstract from their effects. Focusing on this period also has the advantage that labor markets are closer to being competitive, which is the basis of our conceptual framework.

The dataset we use (described in detail in Section 4) has data on white- and blue-collar workers for the manufacturing sector. White-collar workers (empleados) and blue-collar workers (obreros) will be interpreted as skilled and unskilled labor, respectively. Table 1 reports data on wages and employment of both types of workers for the manufacturing sector in Peru during 19942000. The relative wages of skilled workers increase from 2.04 to 2.52 over this period. Relative employment of skilled workers fell slightly, from 0.66 to 0.64 . The share of skilled workers in total wages increased from 0.57 to 0.62 over this period. The real wages of unskilled workers actually declined over this period while that of skilled workers increased by about 20 percent.

Using different information from the Ministry of Labor (Ministerio de Trabajo y Promoción del Empleo), we use the index $(1990=100)$ of wages of white-collar workers (empleados) or skilled labor and blue-collar workers (obreros) or unskilled labor to depict the rising skill premium between 1992 and 2001. Figure 1 shows the evolution of these two indexes. Wages of skilled labor has a positive trend in between 1992 and 2000; instead, wages of unskilled labor remained flat during the same period. These trends show a rising skill premium (wages of skilled labor to wages of unskilled labor) during these years. Looking at the period of study, 1994 to 2000, the annual average wage of skilled labor increased 13 percent, and annual average wage of unskilled labor declined 16 percent. We are unable to use the information from the Ministry of Labor survey because it does not include business information about the other factors of production.

It is interesting to compare these trends with data for the United States, an industrialized country. The annual increase in the skilled wage share ( 0.75 percentage points) in Peru between 


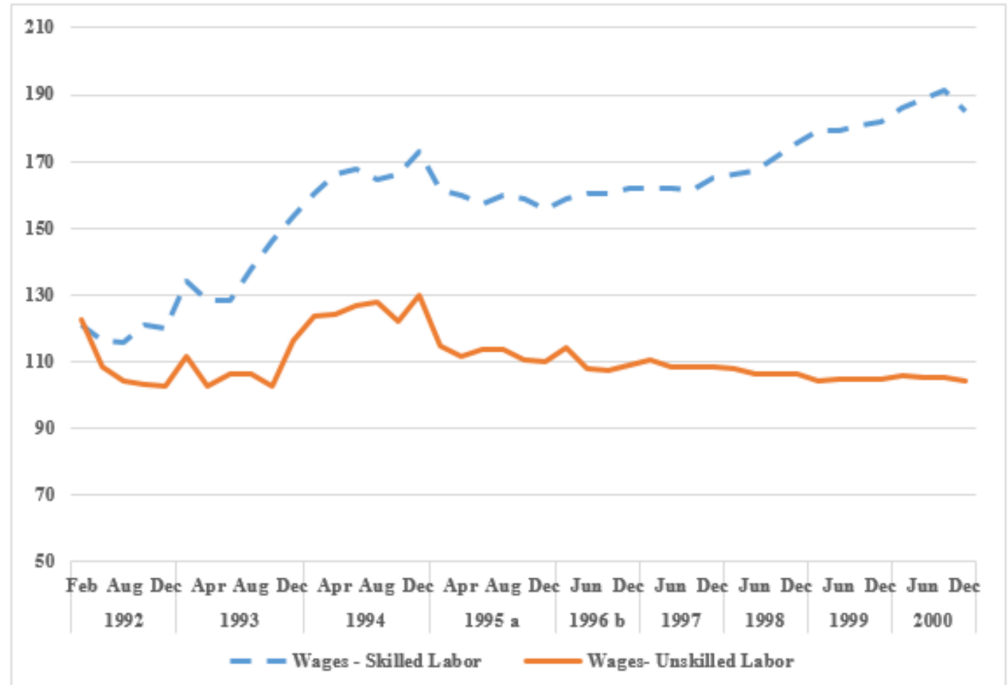

Notes: Survey to business with 10 or more workers conducted by Ministry of Labor and Social Promotion.

a) Change in the sample.

b) Starting 1996, the survey is quarterly.

Source: Compendio Anual 2001, Instituto Nacional de Estadística e Información (2001), Peru.

Figure 1. Wages of skilled and unskilled labor 1992-2000 $(1990=100)$.

1994 and 2000 is very similar to that of the United States between 1979 and 1987 (see Berman et al., 1994). The increase in relative wages is also comparable. The increase in relative wages in Peru implies that wages of skilled workers increased 3.5 percentage points faster per year than wages of unskilled workers. According to Bound and Johnson (1992), the relative wages of male college graduates in the United States to those of high school dropouts with less than 10 years of experience increased from 1.58 to 2.19 over the 1979-1988 period. This implies that wages of college graduates in the United States increased 3.6 percentage points per year faster than that of high school dropouts. On other hand, the ratio of employment of skilled workers increased in the United States during the 1979-1987 period (see Berman et al., 1994) while we do not see much of a change in this ratio in Peru in the 1990s.

\section{Conceptual Framework}

Before presenting the theoretical framework for this paper, we need to answer two questions:

A) Does the increase in relative wages of skilled indicate an increase in the relative demand of skilled workers? We use the methodology by Katz and Murphy (1992) to confirm this increase in the relative demand. It is important to distinguish between labor demand visà-vis labor supply as a source in the changes of relative wages.

B) Are the changes in the wage bill share of skilled labor are due to within-industry changes or between-industry changes. This distinction is important to determine due to our interest on within-industry changes to identify the shifts in relative labor demand and their contributing factors. 
After answering these questions, we continue with our theoretical framework resulting in an equation where the share of each factor of production in total payments will depend on the relative prices of factors of production, capital-output ratio, industry dummy, and time trend.

\section{Preliminary Questions}

A substantial increase in the relative wages of skilled workers without a significant fall in the ratio of employment indicates an increase in the relative demand for this group of workers ${ }^{6}$. We can use the methodology employed by Katz and Murphy (1992) to check whether there was indeed an increase in the relative demand for skilled workers and to estimate its size. If we assume a CES production technology with two factors, we get the following relationship:

$$
\log \left(\omega_{1} / \omega_{2}\right)=(1 / \sigma)\left[D-\log \left(n_{1} / n_{2}\right)\right]
$$

where $\omega$ is the relative wage (of skilled to unskilled), $n$ is the relative employment, period 1 is the latter period, $\sigma$ is the elasticity of substitution between skilled and unskilled, and $D$ is the increase in relative demand for skilled labor.

The estimates of $\sigma$ for the United States reported in Hamermesh (1986) range from 0.49 to $3.7^{7}$. Applying these estimates to the equation above and using the numbers on relative wages and employment in Table 1, we obtain estimates of $D$ that range from 7 to 73 percent over the entire 1994-2000 period. An average of the two estimates of elasticity (i.e., 2.1) yields $D=40$ percent. Therefore, there has been a significant shift in demand in favor of skilled labor.

As Berman et al. (1994) point out, changes in the wage bill share of skilled labor are a good measure of relative demand shifts as long as the elasticity of substitution is greater than 1 . We will focus on this measure in this paper. We perform a between-within decomposition of the wage bill share of the manufacturing sector to see if changes in the overall wage share of skilled labor are due to shifts across industries or changes within industries. The standard way to decompose these changes is as follows:

$$
\Delta S^{\prime}=\sum \bar{S}_{i}^{\prime} \Delta P_{i}+\sum \bar{P}_{i} \Delta S_{i}^{\prime},
$$

where $S^{\prime}$ is the wage share of skilled workers for the manufacturing sector as whole, $S_{i}^{\prime}$ is the skilled wage share in industry $i, P_{i}$ is the share of industry $i$ in total wages. A bar over a variable denotes the mean over the period.

The results of the decomposition are reported in Table 2. As it is clear from the table, the change in the overall wage skilled share is due solely to within-industry changes. The betweenindustry change is actually negative ${ }^{8}$. That is, it will be worthwhile to explore the factors behind these within-industry changes if one wants to understand the relative demand shifts.

\footnotetext{
${ }^{6}$ The relative supply of skilled workers in Peru was fairly stable during this period. Calculations based on data reported by International Labor Organization (2005) show that the relative supply of skilled workers either fell slightly or increased slightly depending on the definition of skilled workers.

${ }^{7}$ These estimates are those obtained from cost function studies and are related to the substitution between all production and non-production workers.

${ }^{8}$ While the shares in output and employment of unskilled labor-intensive industries like textiles and garments did increase during this period, there is no clear pattern in general between skill intensity and changes in industry shares.
} 
Table 2

Between and within decomposition.

\begin{tabular}{lc}
\hline Within & 0.053 \\
Between & -0.011 \\
Total & 0.042 \\
\hline
\end{tabular}

As mentioned before, it is possible that the changes in these shares are driven by measured factors such as capital and materials. Figure 2 shows the trends in these factors over time for the manufacturing sector in Peru. It is clear that capital stock has grown at a much faster rate compared to the other variables ${ }^{9}$. This is different from the United States experience where the capital intensity did not change much over the 1979-87 period. The very large increase in capital intensity in Peru could, also be responsible for the increase in the share of skilled workers. According to the National Accounts published by the National Institute of Statistics and Information (INEI), gross capital formation, 22 percent of gross domestic product, increased 8 percent between 1994 and 2000, despite the recession in 1998 and slow growth in 1999.

\section{Theoretical Framework}

Our estimation is based on a quasi-fixed cost function for gross output. We use the cost function for gross output to take into account the effect of materials, which could also influence labor shares. The cost function is used to derive equations involving shares of skilled and unskilled workers in factor payments (all variable factors). The estimates from these equations will then be used to make predictions about changes in shares in the wage bill. The quasi-fixed cost function assumes that some of the inputs are fixed and the quantities of the variable inputs are chosen to minimize costs. We will assume that the quasi-fixed or variable cost function takes the translog form (see Brown and Christensen, 1981) such as the following:

$$
\begin{aligned}
\ln C V= & \alpha_{0}+\alpha_{Y} \ln Y+\sum_{i} \alpha_{i} \ln P_{i}+\sum_{i} \beta_{i} \ln Z_{i}+\frac{1}{2} \gamma_{Y Y}(\ln Y)^{2}+\frac{1}{2} \sum_{i} \sum_{j} \gamma_{i j} \ln P_{i} \ln P_{j} \\
& +\frac{1}{2} \sum_{i} \sum_{j} \delta_{i j} \ln Z_{i} \ln Z_{j}+\sum_{i} \rho_{Y i} \ln Y \ln P_{i}+\frac{1}{2} \sum_{i} \sum_{j} \rho_{i j} \ln P_{i} \ln Z_{j}+\sum_{i} \prod_{i} \ln Y \ln Z_{i} \\
& +\alpha_{A} \ln A+\frac{1}{2} \alpha_{A A}(\ln A)^{2}+\alpha_{A Y} \ln A \ln Y+\sum_{i} \alpha_{A P_{i}} \ln A \ln P_{i}+\sum_{i} \alpha_{A Z_{i}} \ln A \ln Z_{i},
\end{aligned}
$$

where $Y$ is gross output, $P_{i}$ is price of variable input $i, Z_{i}$ is the quantity of fixed input $i$, and $A$ measures the level of technology.

We assume that there are four variable inputs and one fixed input. The variable inputs are skilled labor, unskilled labor, domestic materials, and imported materials. The fixed input is capital.

The derivative $\partial \ln C V / \partial \ln P_{i}$ will equal the share $\left(S_{i}\right)$ of the variable factor $i$ in variable cost. Therefore, we have

\footnotetext{
${ }^{9}$ Capital intensity, as measured by the capital to value added ratio, increased from 0.74 to 1.38 from 1994 to 2000. Such large increases in capital intensity have been observed in other developing countries as well. Roberts (1996), for example, reports that the average capital-output ratio of manufacturing industries in Colombia more than doubled between 1977 and 1985.
} 


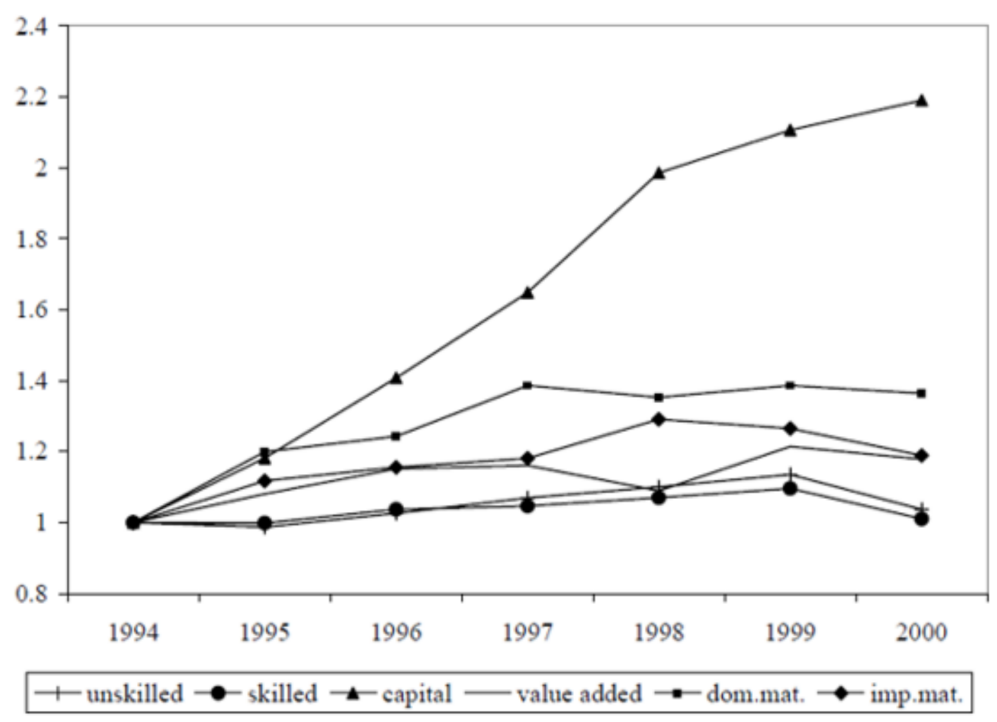

Source: Encuesta Anual de Manufactura, Ministerio de Industria, Turismo, Integración y Negociaciones Comerciales Internacionales (1995-2001), Peru.

Figure 2. Evolution of factors of production $(1994=1)$.

$$
S_{i}=\frac{\partial \ln C V}{\partial \ln P_{i}}=\alpha_{i}+\rho_{Y i} \ln Y+\sum_{j} \gamma_{i j} P_{j}+\sum_{j} \rho_{i j} Z_{j}+\alpha_{A P_{i}} \ln A,
$$

where $S_{i}$ is the share of factor $i$ in total payments to variable factors. The first equality in (2) comes from the assumption of cost minimization while the second equality comes from taking derivatives of equation (1).

We need to assume $\gamma_{i j}=\gamma_{j i}$ so that the cross partials of the translog cost function with respect to the $\log$ of prices are the same. We also need $\sum_{j} \gamma_{j i}=0$ for the cost function to be homogeneous of degree one in input prices. If we impose constant returns to scale then we will have $\rho_{Y i}+\sum_{j} \rho_{j i}$.

We will assume that $\ln A$ takes the form

$$
\ln A=\beta_{k}+\beta_{t} t+\varepsilon_{k t},
$$

where $k$ denotes industry, $t$ denotes time, and $\varepsilon_{k t}$ is a random error term. The technology term has industry, time, and random components. We will assume that $\beta_{t}$ is positive, i.e., technology improves over time. Equation (2) can be rewritten as

$$
S_{i}=\frac{\partial \ln C V}{\partial \ln P_{i}}=\alpha_{i}+\rho_{Y i} \ln Y+\sum_{j} \gamma_{i j} \ln P_{j}+\sum_{j} \rho_{i j} Z_{j}+\left(\alpha_{A P_{i}} \beta_{k}+\alpha_{A P_{i}} \beta_{t} t+\alpha_{A P_{i}} \varepsilon_{k t}\right) .
$$

Let us look at the expression for the error term (within parentheses) in equation (2') above (the industry and the time subscripts have been omitted from the other variables for the sake of clarity). The first term is an industry specific term. The second term is a function of time and will be negatively related to time variable if $\alpha_{A P_{i}}<0$. A negative $\alpha_{A P_{i}}$ will imply that technological change is biased against factor $i$. The last term within parentheses is a random term.

Consequently, Equation (2') can be estimated using an industry fixed effect, a time trend, $\log$ of price indices of the variable inputs, and the log of capital and gross output. The actual 
equation to be estimated (after imposing all necessary constraints) takes the form

$$
\begin{aligned}
S_{i}= & \alpha_{i}+\gamma_{i S} \ln \left(\frac{w_{S}}{p_{D}}\right)+\gamma_{i U} \ln \left(\frac{w_{U}}{p_{D}}\right)+\gamma_{i M} \ln \left(\frac{p_{M}}{p_{D}}\right)+\rho_{i K} \ln \left(\frac{K}{Y}\right) \\
& + \text { industry dummy + time trend + error term },
\end{aligned}
$$

where $w$ denotes wage, the subscripts $S$ and $U$ denote skilled and unskilled labor, respectively; $p$ denotes price of materials, the subscripts $D$ and $M$ denote domestic and imported, respectively; and $K$ denotes capital.

We have an equation for each of the four variable factors: skilled labor, unskilled labor, imported materials, and domestic materials. These equations will be estimated as a system. Only three of these equations will be linearly independent. We will drop the share equation involving domestic materials and estimate the remaining three using iterative Seemingly Unrelated Regressions (SUR). Since the iterative procedure is used, the estimates will not be sensitive to the equation being dropped. One point to note is that we assume that there is no correlation between capital and shocks affecting factor shares. This is reasonable since the capital stock for year $T$ does not include investment in year $T$. While the latter could be correlated with year $T$ shocks, the capital stock should not. Also, investment may not respond to year-to-year shocks since the planning horizon for new investment is likely to be longer than a year.

\section{Data and Results}

\section{Data}

Our data comes from the Annual Survey of Manufactures for Peru collected by Ministerio de Industria, Turismo, Integración y Negociaciones Comerciales Internacionales (MITINCI). The data are available at the four-digit ISIC (Rev. 3) level and includes information on employment, wages, value added, materials, investment, and capital stock for firms with five or more workers. The data are available from 1994 to $2000^{10}$. The survey covers approximately 90 percent of the gross value of production of 1994, the base year.

The survey has information on white-collar and blue-collar workers and, as mentioned before, we interpret these as skilled and unskilled labor, respectively. To compute payments to these two types of workers, we take into account both wage and non-wage payments. The wage payments are available for each type of worker. The non-wage payments are not available separately for the two types of workers and so are allocated to each type according to their share in the wage bill. Non-wage payments include health plan payments, accident insurance payments, manufacturing

\footnotetext{
${ }^{10}$ Previous surveys cover the period from 1988 to 1992 . However, the data from these years are not easily comparable to that of the latter period because of changes in industry classification. Starting in 2001, there were several changes in the methodology regarding the compilation of respondents, survey questions and industry classification. Due to these changes, we are not able to compare information with the following years or analyze a longer period. Currently, we are working on a similar research that covers the last ten years. For more details in the change in this survey can be found in the website of Encuesta Anual de Empresas 2011 (Annual Survey of Enterprises 2011) in the National Institute of Statistics and Information (INEI): http://webinei.inei.gob.pe/anda_inei/index.php/catalog/154.
} 
training fund payments (SENATI), contributions to the national housing fund (FONAVI), tenure bonus payments, and Christmas and national holiday bonuses. We constructed price indices for materials to get estimates of the quantities of materials, both domestic and imported. We were able to obtain these indices only at the level of input-output (IO) industries for Peru. Both domestic and import price indices (base year 1994) were available at the IO level from the Compendio Estadistico, published by the National Institute of Statistics and Information (INEI). The 1994 IO table for Peru gives the flows of both domestically produced commodities as well as imports into each industry. A price index for materials was constructed by taking the weighted average of the price indices of commodities with the 1994 shares of each commodity in total intermediate use as weights ${ }^{11}$. Separate price indices were computed for domestic and imported materials to deflate these two variables. The payments to these factors were the nominal values of these variables ${ }^{12}$.

\section{Capital Stock Estimation}

We employed a perpetual inventory method to obtain estimates of the capital stock. That is, the beginning of period capital stock in period $t, K_{t}$, is given by

$$
K_{t}=(1-\delta) K_{t-1}+I_{t-1}
$$

where $\delta$ is the depreciation rate and $I$ is investment (at base year prices). The depreciation rate used for equipment was 12.3 percent and for structures was 3.6 percent (based on United States data from Jorgenson et al., 1999, ch. 4). The initial capital stock used was the one available for 1994 from the survey ${ }^{13}$.

The wage rates on the right hand side of equation (2") were calculated at the level of manufacturing sector as a whole for each year (obtained as total wage payments divided by total employment). The assumption here is that wages are the same across industries due to mobility of both types of labor, which has been the standard practice in the literature ${ }^{14}$. Wages, therefore,

\footnotetext{
${ }^{11}$ Note that this is the same as a Tornqvist chain price index assuming the shares of each commodity in total intermediate use stay the same over time. The Tornqvist chain price index is computed as follows:

$$
\ln \frac{P_{T}}{P_{0}}=\sum_{t} \sum_{i} 0.5\left(s_{i t}+s_{i t-1}\right) \ln \left(\frac{P_{i t}}{P_{i t-1}}\right),
$$

where $t=1$ to $T, s$ is the value share of commodity $i$ (see Kohli, 1991, ch.8).

${ }^{12}$ These also include taxes on fuels. Taxes on fuels were allocated to domestic and imported materials according to their shares in total material use.

${ }^{13}$ The survey reports the end-of-year capital stock and investment during that year. The beginning-of-year capital stock for 1994 was estimated using the end-of-year capital stock, and investment data for 1994, and the rates. The capital stock for subsequent years was estimated using the perpetual inventory method mentioned before. One problem with the capital data for 1994 is that the survey reports the capital stock data at book value. This can introduce both upward and downward biases in the capital stock measure. The capital stock may be overstated since depreciation is not taken into account. The stock may be understated since investment acquired in years prior to 1994 will be valued at the prices of the years they were acquired instead of 1994 prices and prices tend to increase over time (see Roberts, 1996). The problem may be alleviated somewhat by the fixed effects.

${ }^{14}$ Since observed wages do differ across industries, the implicit assumption here is that such variations arise from differences in quality and that the quality adjusted wage is the same across industries. Actual industry wages cannot be used in the regression since they are endogenous.
} 
vary only across time (however, the wage shares, which are the dependent variables in the system of equations, do vary across both industry and time). The wage variables used in the regression are indices with 1994 as the base year.

\section{Estimation Procedure}

The estimation procedure will involve several steps:

I. Run a standard model to analyze the determinants of the changing wage share of skilled workers.

II. Estimate an equation involving the difference in the share of skilled workers and unskilled workers using equation (2").

III. Estimate the entire system of equations presented in (2").

IV. Estimate the magnitude of the increase in share of skilled workers and their relative wages over the 1995-2000 period explained by accumulation of capital.

v. Test for the assumption of separability, addressing the use value added vis-à-vis output in the regression.

The first two steps will provide a reference for comparison to our results for the equation system. The last two steps will support the results and methodology.

The sample period for all regressions is $1995-2000^{15}$.

\section{Standard Model}

Before we estimate equation (2") we run a regression involving the share of skilled workers in the total wage bill as the dependent variable. This has been the standard way to analyze the determinants of the changing share of skilled workers (see, for example, Berman et al., 1994; Pavcnik, 2003). The equation takes the form

$$
S^{\prime}=a+b_{1} \ln \left(\frac{w_{S}}{w_{U}}\right)+b_{2} \ln \left(\frac{K}{V}\right)
$$

where $S^{\prime}$ is the share of skilled workers in total wage bill; $w_{S}$ and $w_{U}$ are wages of skilled and unskilled labor, respectively; $K$ is capital; and $V$ is value added.

The theoretical basis of the equation is a quasi-fixed translog cost function for value added with the usual homogeneity restrictions and constant returns to scale assumption imposed. Capital is taken to be the fixed input while the two types of labor are variable. The results of this estimation, with and without a time trend, are reported in Table 3b. The capital to value added ratio is significant at the 10 percent level. The time variable is positively related to the skilled share but is not significant.

\footnotetext{
${ }^{15}$ We do not include 1994 in our sample since the mismeasurement problem is likely to be more severe with the capital stock data for 1994.
} 
Table 3

Determinants of the changing wage share of skilled workers: standard model.

(a) Descriptive statistics.

\begin{tabular}{lcccc}
\hline & Mean & Standard Deviation & Minimum & Maximum \\
\hline Skilled share in wage bill & 0.58 & 0.11 & 0.27 & 0.92 \\
Skilled to unskilled relative wage & 0.87 & 0.04 & 0.81 & 0.94 \\
Capital to value added ratio & -0.36 & 0.84 & -6.37 & 3.66 \\
\hline
\end{tabular}

(b) Regression results.

\begin{tabular}{lcc}
\multicolumn{3}{l}{ Dependent variable: skilled share in wage bill (with industry dummies) } \\
\hline & Regression 1 & Regression 2 \\
\hline Relative wage & 0.081 & 0.013 \\
& $(0.06)$ & $(0.12)$ \\
Capital to value added ratio & $0.011^{*}$ & $0.01^{*}$ \\
& $(0.006)$ & $(0.006)$ \\
Time & & 0.002 \\
& & $(0.003)$ \\
R2 (adjusted) & 0.77 & 0.77 \\
Number of observations & 552 & 552 \\
\hline
\end{tabular}

Note: Number in parenthesis are standard errors.

*** and ${ }^{*}$ significant at $1 \%$ and $10 \%$ levels respectively.

One problem with this specification could be that the production function is not separable between labor and capital variables on one hand and materials on the other. The equation could, therefore, be misspecified. We will show later that the null hypothesis of separability is rejected by the data.

\section{Difference in the Share of Skilled Workers and Unskilled Workers}

We now go back to the share equations based on our framework involving a gross output cost function. Equation (2") gives us a system of equations, one for each variable factor of production. Before we estimate the entire system of equations, we estimate an equation involving the difference in the share of skilled workers and unskilled workers using equation (2"). That is, we estimate an equation of the form

$$
\begin{aligned}
S_{S}-S_{U}= & \left(\alpha_{S}-\alpha_{U}\right)+\left(\gamma_{S S}-\gamma_{U S}\right) \ln \left(\frac{w_{S}}{p_{D}}\right)+\left(\gamma_{S U}-\gamma_{U U}\right) \ln \left(\frac{w_{U}}{p_{D}}\right)+\left(\gamma_{S M}-\gamma_{U M}\right) \ln \left(\frac{p_{M}}{p_{D}}\right) \\
& +\left(\rho_{S K}-\rho_{U K}\right) \ln \left(\frac{K}{Y}\right)+\text { industry dummy + time trend + error term. }
\end{aligned}
$$

The results are reported in the first column of Table $4 \mathrm{~b}$. The capital-output ratio is highly correlated with the difference between skilled and unskilled wage share. An increase in the capital to output ratio of 10 percent will increase the difference in the share by 0.1 percentage points, which is about 4 percent of the mean share difference.

Figure 3 plots the change in the difference between skilled and unskilled wage against change in the log of capital to gross output ratio over the period 1995-2000. There is a very clear positive relationship between the two variables. 
Table 4

Difference in the share of skilled workers and unskilled workers: equation system.

(a) Descriptive statistics.

\begin{tabular}{lcccc}
\hline & Mean & Standard Deviation & Minimum & Maximum \\
\hline $\begin{array}{l}\text { Skilled share - unskilled share } \\
\text { in payments to variable factors }\end{array}$ & 0.027 & 0.048 & -0.18 & 0.28 \\
$\begin{array}{l}\text { Skilled share in payments to } \\
\text { variable factors }\end{array}$ & 0.093 & 0.046 & 0.008 & 0.32 \\
$\begin{array}{l}\text { Unskilled share in payments } \\
\text { to variable factors }\end{array}$ & 0.067 & 0.039 & 0.011 & 0.29 \\
$\begin{array}{l}\text { Imported materials share in } \\
\text { gross output }\end{array}$ & 0.18 & 0.15 & 0 & 0.62 \\
$\begin{array}{l}\text { Ln (skilled wage/price of } \\
\text { domestic materials) }\end{array}$ & 0.22 & 0.09 & -0.16 & 0.44 \\
$\begin{array}{l}\text { Ln(unskilled wage/price of } \\
\text { domestic materials) }\end{array}$ & 0.087 & 0.074 & -0.365 & 0.292 \\
$\begin{array}{l}\text { Ln(price imported mat./price } \\
\text { domestic materials) }\end{array}$ & 0.023 & 0.08 & -0.347 & 0.53 \\
Ln(capital/gross output) & -1.51 & 0.79 & -7.19 & 0.41 \\
\hline
\end{tabular}

(b) Regression results.

\begin{tabular}{lccc}
\hline & \multicolumn{1}{c}{ OLS } & \multicolumn{2}{c}{ Iterative SURE } \\
\hline & $\begin{array}{l}\text { Dep. Variable: Skilled - } \\
\text { unskilled share in } \\
\text { payments to variable } \\
\text { factors }\end{array}$ & $\begin{array}{l}\text { Dep. Variable: Skilled } \\
\text { share in payments to } \\
\text { variable factors }\end{array}$ & $\begin{array}{l}\text { Unskilled share in } \\
\text { payments to variable } \\
\text { factors }\end{array}$ \\
& -0.025 & -0.005 & 0.013 \\
\hline Ln(Skilled wage/price of & $(0.052)$ & $(0.029)$ & $(0.024)$ \\
domestic material) & -0.012 & 0.013 & 0.037 \\
Ln(Unskilled wage/price of & $(0.051)$ & $(0.024)$ & $(0.027)$ \\
domestic material) & $0.04^{*}$ & 0.023 & -0.022 \\
Ln(price imported material/ & $(0.024)$ & $(0.02)$ & $(0.018)$ \\
price domestic material) & $0.01^{* * *}$ & $0.015^{* * *}$ & $0.004^{*}$ \\
Ln(capital/gross output) & $(0.003)$ & $(0.003)$ & $(0.002)$ \\
Time & 0.0003 & $-0.0016^{*}$ & $-0.002^{* * *}$ \\
R squared & $(0.0014)$ & $(0.0009)$ & $(0.0008)$ \\
$\mathrm{N}$ & 0.78 & 0.81 & 0.79 \\
\hline
\end{tabular}

Note: Number in parenthesis are standard errors.

*** and ${ }^{*}$ significant at $1 \%$ and $10 \%$ levels respectively.

\section{Estimating the Entire System of Equations}

We next run the system of equations described by (2") using iterative SURE. The results for the skilled and unskilled wage share equations are reported in the last two columns of Table 4b. In this table we report the results for the equations where the dependent variables are the wage share of skilled labor in payments to variable factors, and the wage share of skilled labor in payments to variable factors. The independent variables are skilled wage to price of domestic materials, unskilled wage to price of domestic materials, price of imported materials to price of domestic materials, capital to gross output ratio, and time trend. 


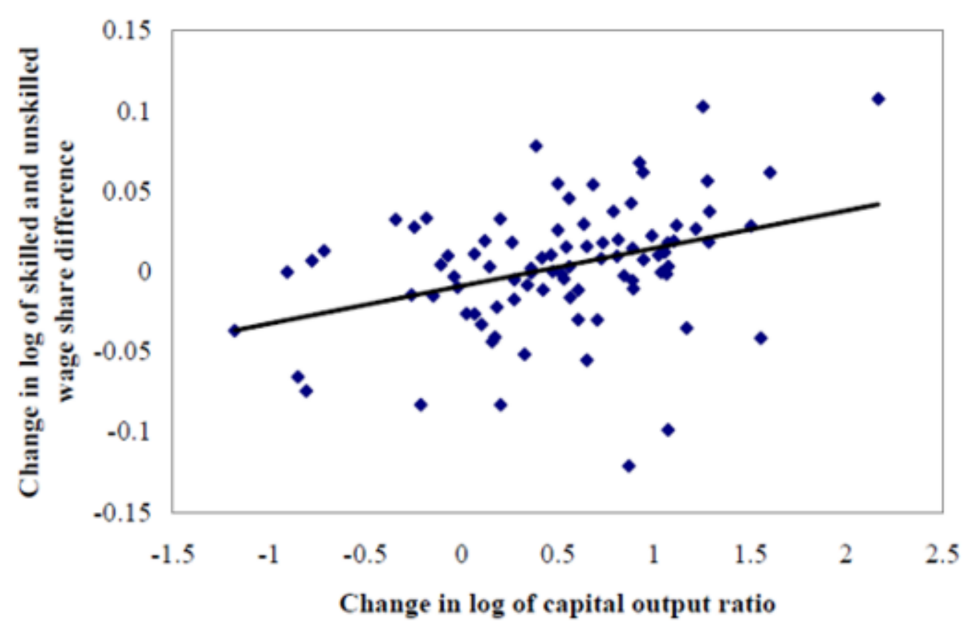

Source: Encuesta Anual de Manufactura, Ministerio de Industria, Turismo, Integración y Negociaciones Comerciales Internacionales (1995-2001), Peru.

Figure 3. Correlation between skilled and unskilled wage share difference and capital intensity (1995-2000).

Both skilled and unskilled wage shares are positively related to the capital to output ratio. However, the point estimate is higher in the skilled wage share regression. The difference in the estimates between the skilled and unskilled wage share is 0.011 , which is consistent with the results of estimation of equation (4) involving the difference in shares. It is interesting to note that technological change, as measured by the time variable, has been biased against both skilled and unskilled workers. The negative bias is stronger for unskilled workers. The time trend is, however, not significantly related to the difference in shares, as reported in the first column of this table. It is also interesting to note that the relative price of imported materials is actually positively related to the skilled wage share, indicating these two factors may be substitutes. Unskilled wage shares appear to increase with a decrease in price of imported materials. All this is consistent with the hypothesis that imported materials may embody skilled labor for developing countries. The coefficients for price of imported materials are, however, not significant. The imported material price is significant at the 10 percent level, however, in the regression involving the difference in the shares (reported in the first column of this table).

\section{How Much Can Capital Accumulation Explain?}

We want to estimate how much of the increase in share of skilled workers and their relative wages over the 1995-2000 period can be explained by accumulation of capital. The share of skilled workers in the wage bill is equal to $S S /(S S+S U)$, where $S S$ and $S U$ are the shares of skilled and unskilled workers in the payments to all variable factors. We estimate the changes in the skilled and unskilled shares in variable factor payments between 1995-2000 predicted by the increase in the capital to gross output ratio for each industry using the results of the SUR regression reported in Table 4b. These estimates are then used to obtain the corresponding changes in skilled share in the wage bill. The actual and estimated mean changes (across industries) of the skilled share 
Table 5

Contribution of increases in capital intensity to changes in skilled labor share in wage bill and relative wages.

\begin{tabular}{lc}
\hline Actual mean change (across industries) in skilled share in wage bill & 0.014 \\
Estimated mean change in skilled share in wage bill from increase in capital & 0.011 \\
intensity & \\
Actual change in the skilled share in wage bill of the manufacturing sector & 0.024 \\
Estimated change in the skilled share in wage bill of the manufacturing sector & 0.009 \\
from increases in capital intensity & \\
$\begin{array}{l}\text { Actual change in the log of skilled to unskilled wage ratio of the manufacturing } \\
\text { sector }\end{array}$ & 0.12 \\
$\begin{array}{l}\text { Estimated change in the log of skilled to unskilled wage ratio of the manufac- } \\
\text { turing sector from increases in capital intensity }\end{array}$ & 0.058 \\
\hline
\end{tabular}

in the wage bill are reported in the first panel of Table 5. As can be seen, capital accumulation can explain almost the entire increase in the mean wage bill share of skilled workers.

We also want to estimate how much of the increase in the share of skilled workers in the manufacturing sector as a whole can be explained by increases in capital intensity (as measured by the capital to gross output ratio). Increases in the capital stock have increased the withinindustry wage shares of skilled labor. As was shown in Section 2, the change in the overall share of skilled workers in the wage bill of the manufacturing sector can be decomposed into a within-industry component and a between-industry component. We want to see how much capital accumulation has contributed to the within-industry component. This contribution is equal to $\sum \bar{P}_{l} \Delta \hat{S}_{l}^{\prime}$, where $\bar{P}_{l}$ is the mean (over the time period) share of industry $i$ in total wages and $\Delta \hat{S}_{l}^{\prime}$ is the predicted share of skilled labor in the wage bill for industry $i$, obtained using the coefficients of the SUR regression and changes in capital intensity (calculation of these share changes was described in the previous paragraph). That is, we calculate the weighted sum of the changes in the skilled wage share predicted by capital accumulation. This contribution and the actual change in the skilled wage share in the manufacturing sector are reported in the second panel of Table 5. Increases in capital intensity explain close to 40 percent of the increase in the skilled wage share in the manufacturing sector as a whole.

We also want to see how much of the increase in relative wages in the manufacturing sector as a whole can be explained by increases in capital. This is done by using the fact that

$$
\Delta \log \left(\frac{w_{S}}{w_{U}}\right)=\Delta \log \left(\frac{S_{S}^{\prime}}{S_{U}^{\prime}}\right)-\Delta \log \left(\frac{n_{S}}{n_{U}}\right),
$$

where $w$ denotes wage, $S^{\prime}$ denotes share in wage bill and $n$ denotes employment. We can estimate how much the relative wages would have to change given the changes in the shares of skilled and unskilled workers predicted by increases in capital intensity. We take the change in the (log) employment ratio as given and equal to the actual change. The predicted and actual changes in $(\log )$ relative wages are reported in the last panel of Table 5. Capital intensity increases explain close to 50 percent of the actual change in relative wages in the manufacturing sector. 
Table 6

Changes in skilled labor share predicted by value added regressions versus changes predicted by gross output regressions.

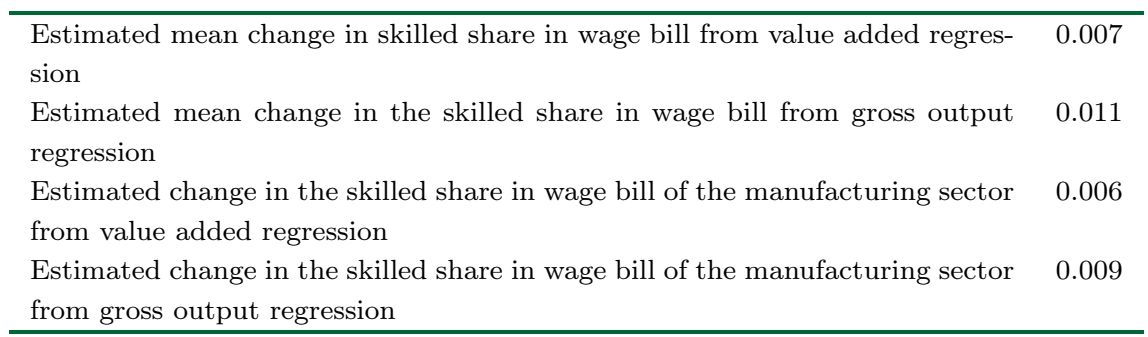

\section{Testing for the Assumption of Separability}

As mentioned before, share equations based on value added function could be misspecified since the assumption of separability may not be valid. This could be one reason why we see a weaker relationship between capital intensity and skilled labor demand in the share equation involving value added. Table 6 compares the change in the wage share of skilled labor that can be explained by the value added regressions (reported in Table 3b) with the change that can be accounted for by the gross output regressions. The mean change predicted by the value added regression ${ }^{16}$ is about 60 percent of the mean change predicted by the gross output regression. The change predicted by the value added regressions for the manufacturing sector as a whole is about two-thirds of that predicted by the gross output regressions. It is useful, therefore, to conduct a test for separability.

We can have a value added function that depends only on capital and labor only if the gross output function is of the form

$$
Y(S, U, K, M)=Y(V(S, U, K), M)
$$

where $Y$ is gross output, $V$ is real value added, $S, U$, and $K$ are skilled labor, unskilled labor and capital, respectively and $M$ is a vector of materials (domestic and imported).

The cost function will be separable between the prices of labor and capital inputs on one hand and material inputs prices on the other if the production function is separable with respect to these two sets of inputs (as shown above). A cost function, c, is said to be separable with respect to a partition of inputs if the following holds

$$
\frac{\partial\left(c_{j} / c_{k}\right)}{\partial p_{M}}=0
$$

where the subscripts for the cost function denote partial derivatives, $j$ and $k$ denote inputs belonging to one subset resulting from the partition, and $p_{M}$ is the price of input $m$ belonging to the other subset (see Kohli, 1991, ch.4). That is, the ratio of quantities of inputs belonging to

\footnotetext{
${ }^{16}$ The change for each industry is obtained by multiplying the coefficient for capital intensity reported in Table $3 \mathrm{~b}$ with the change in the log of capital to value added ratio of that industry. The method for obtaining changes predicted by the gross output regression has been explained above.
} 
Table 7

Test for separability of production function.

\begin{tabular}{lc}
\hline Likelihood ratio & 18.3 \\
Number of restrictions & 5 \\
$\chi_{0.01,5}^{2}$ & 15.09 \\
\hline
\end{tabular}

one subset of the partition should be independent of the prices of inputs of the other subset. This would require - e.g., in the case where capital $(K)$ and labor $(L)$ are separable from materials $(M)-\sigma_{K M}=\sigma_{L M}$, where $\sigma$ denotes the Allen-Uzawa elasticity of substitution.

The condition stated above refers to the total cost function where all inputs are variable. Since we estimate a quasi-fixed cost function, we need to relate our estimates to the parameters of the total cost function. Brown and Christensen (1981) show how this can be done. It can be shown that a sufficient condition for separability to hold for the system of equations described by (2") is

$$
\gamma_{S M}=\gamma_{U M}=\gamma_{S D}=\gamma_{U D}=\rho_{K M}=0 .
$$

We test this restriction using the likelihood ratio test. The results are reported in Table 7 . The likelihood ratio statistic is 18.3 , which is greater than the critical value of the $\chi^{2}$ distribution at the 1 percent level. The null hypothesis that the separability restrictions hold is therefore rejected. Using the gross output framework and incorporating the role of materials make a difference.

\section{Conclusion}

We show in this paper that there has been a substantial shift in demand in favor of skilled workers in Peru during the latter half the 1990s. This increase in demand has been observed in other developing countries as well in recent years. There is a widely held view that unobserved skilled biased technological change is behind this development. We show in this paper that capital accumulation can explain a large portion of this shift towards skilled labor in Peru. In addition, increased availability of imported materials seems to decrease the relative demand for skilled workers, perhaps because materials that are imported into a developing country such as Peru embody skilled labor. Conte and Vivarelli (2011) study 23 low and middle-income countries, including Peru for the years 1980-1988, and find that capital-skill complementarity is a possible source of skill bias. In addition, the authors conclude that imported skill-enhancing technology could be an additional factor for an increasing demand for skilled workers in these countries, contributing to the rising skill premium.

The shift in demand towards skilled labor has been observed in both developing and developed countries. While there are similarities associated with this phenomenon between these two sets of countries, there could be important differences. We observe, for example, that the employment ratio has not changed much in Peru while that is not the case in the United States. There is a sharp increase in capital intensity in Peru, which we do not observe in the United States. The latter difference could account for why we see that capital accumulation can explain a large fraction of the shift in demand towards skilled labor in Peru but not in the United States. One 
implication of our results is that if trade stimulates investment in developing countries then it could also increase the relative demand for skilled labor in the presence of strong capital-skill complementarities.

Conte and Vivarelli (2011) econometric results indicate that capital deepening is responsible for relative shifts towards skilled labor. In contrast, SETI appears to be the crucial determinant of an absolute diverging path between skilled and unskilled employment in low- and middle-income countries.

Indeed, the transferred technology embodied in imports of industrial machinery, equipment, and ICT capital goods involves a significant increase in the demand for skilled workers, while it has no significant impact on the demand for the unskilled.

\section{References}

Berman, E., Bound, J., and Griliches, Z. (1994). Changes in the Demand for Skilled Labor within US Manufacturing: Evidence from the Annual Survey of Manufacturers. Quarterly Journal of Economics 109(2), 367-97.

Berman, E., and Machin, S. (2000). Skill-Biased Technology Transfer around the World. Oxford Review of Economic Policy 16(3), 12-22.

Bound, J., and Johnson, G. (1992). Changes in the Structure of Wages in the 1980s: An Evaluation of Alternative Explanations. American Economic Review 82(3), 371-92.

Brown, R., and Christensen, L. (1981). Estimating Elasticities of Substitution in a Model of Partial Static Equilibrium: An Application to U.S. Agriculture, 1947 to 1974. In E. Berndt and B. Field (Eds.). Modeling and Measuring Natural Resource Substitution. Cambridge, Massachusetts, and London: MIT Press.

Conte, A., and Vivarelli, M. (2011). Imported Skill-Biased Technological Change in Developing Countries. The Developing Economies 49(1), 36-65.

Davis, D. (1996). Trade Liberalization and Income Distribution. NBER Working Paper No. 5693.

Feenstra, R., and Hanson, G. (1996). Foreign investment, outsourcing, and relative wages. In R. Feenstra, G. Grossman and D. Irwin (Eds.). The Political Economy of Trade Policy. Cambridge, Massachusetts, and London: MIT Press.

Feenstra, R., and Hanson, G. (1999). The Impact of Outsourcing and High Technology Capital on Wages: Estimates for the United States, 1979-1990. Quarterly Journal of Economics $114(3), 907-40$.

Griliches, Z. (1969). Capital-Skill Complementarity. The Review of Economics and Statistics 51(4), 465-468.

Hamermesh, D. (1986). The Demand for Labor in the Long Run. In O. Ashenfelter and R. Layard (Eds.). Handbook of Labor Economics, Vol. 1. Amsterdam, Oxford, and Tokyo: North Holland.

Hanson, G., and Harrison, A. (1999). Trade Liberalization and Wage Inequality in Mexico. Industrial and Labor Relations Review 52(2), 271-88.

Instituto Nacional de Estadística e Información. (2001). Perú: Compendio Anual. Lima. 
International Labor Organization. (2005). World Employment Report 2004-05: Employment, productivity and poverty reduction. Geneva.

Inter-American Development Bank. (2004). Good Jobs Wanted: Labor Markets in Latin America. Economic and Social Progress in Latin America, Report. Washington, D.C.

Jorgenson, D., Gollop, F., and Fraumeni, B. (1999). Productivity and U.S. Economic Growth. Harvard University Press.

Katz, L. and Murphy, K. (1992). Changes in Relative Wages, 1963-1987: Supply and Demand Factors. The Quarterly Journal of Economics 107(1), 35-78.

Kohli, U. (1991). Technology, Duality and Foreign Trade: The GNP Function Approach to Modeling Imports and Exports. Ann Arbor: The University of Michigan Press.

Krusell, P., Ohanian, L., Rios-Rull, J., and Violante, G. (2000). Capital-Skill Complementarity and Inequality: A Macroeconomic Analysis. Econometrica 68(5), 1029-53.

Ministerio de Industria, Turismo, Integración y Negociaciones Comerciales Internacionales (19952001). Perú: Encuesta Anual de Manufactura. Lima.

Pavcnik, N. (2003). What Explains Skill Upgrading in Less Developed Countries? Journal of Development Economics 71(2), 311-28.

Robbins, D. (1996). HOS Hits Facts: Facts Win; Evidence on Trade and Wages in the Developing World. Harvard Institute for International Development, Development Discussion Paper No. 557.

Roberts, M. (1996). Colombia, 1977-85: Producer Turnover, Margins and Trade Exposure. In M. Roberts and J. Tybout (Eds.). Industrial evolution in developing countries: micro patterns of turnover, productivity, and market structure. New York: Oxford University Press.

Saavedra, J., and Torero, M. (2000). Labor Market Reforms and Their Impact on Formal Labor Demand and Job Market Turnover: The case of Peru. Inter-American Development Bank, Research Network Working Paper No. R-394.

Wood, A. (1997). Openness and wage inequality in developing countries: the Latin American Challenge to East Asian Conventional Wisdom. The World Bank Economic Review 11(1), 33-57. 